\title{
CREATING PREHISTORY: ARCHAEOLOGY MUSEUMS AND THE DISCOURCE OF MODERNISM
}

\author{
Bjørnar Olsen \\ Asgeir Svestad
}

In the 19th century a number of new scientific disciplines made their appearance in Europe. Among these was archaeology, a discipline concerned with man's very distant past. Archaeology unfolded in a space created by the collapse of the pre-modern, biblical conception of history. This breakdown had left a void which archaeology, along with several other evolutionary disciplines, were able successfully to fill. By the end of the 19th century a vast number of archaeological collections, exhibitions and museums had grown up throughout Europe and stood as material signifiers of the newly established time-depth of man.

If one reads research histories of archaeology two seemingly contradictory views on this development are noted. The first, and most traditional viewpoint, depicts the birth of archaeology as a consequence of fundamental discoveries made by certain gifted individuals. These texts focus on Thomsen's discovery of the three-age system, Worsaae's divison of the Stone Age, or on Boucher de Perthes' Paleolithic discoveries (e.g. Daniel 1971, 1978, Klindt Jensen 1975). The second position, which has attracted a growing number of supporters in recent years, maintains that the early development of archaeology must be understood in relation to the social and political demands of contemporary society (e.g. Kristiansen 1981, Patterson 1986,
Trigger 1989).

In this paper we will propose a slightly different approach to the analysis of how prehistory became the object of a disciplinary discourse, paying special attention to the role played in this process by statements and practices associated with the archaeology museums. In brief, we argue that the concept of prehistory was not a reality which preceded either an archaeological discourse or modernity. Prehistory, as it came to be perceived and thought of, was not an unrevealed secret which was waiting for its discoverers. Archaeological discourse was instead shaping this concept of prehistory in a mould which was handed to it by the modern episteme.

Thus, the aim of this paper is not to 
4 investigate traditional historiographic puzzles such as: who "discovered" prehistory, or who "invented" archaeology or the first proper museums. We are concerned with questions of a different kind: At what time did it become possible to talk about a history and a prehistory? What rules and techniques have made it possible to create "prehistory" as an object of knowledge; to separate it from other fields of knowledge?

It is in this process that we believe the museum, as a kind of "disciplinary techno$\log y "$ ", played a decisive role. Rather than regarding it as purely a reflection of ideas created in advance in the minds of great thinkers, we will argue that the 19th century museum played a creative and material role in the construction and enclosure of an archaeological field of knowledge. Exhibitions, collections and the museum buildings themselves "functioned" to make the past visible and concrete. In a very literal sense, they objectified prehistory as a separate and internally coherent subject matter. Moreover, the museum supplied the discipline with an institutionalized space, a supportive base from which serious speech acts about the past could be uttered.

\section{CONCEPTION OF THE PAST ON THE THRESHOLD TO MODERNITY}

Until the end of the 18th century the creationist view of man's history prevailed in Europe. God's creation of the earth and of all organisms, Noah's flood, and biblical chronology in general constituted the basis of a universal history. The world was believed to be of recent, supernatural origin and its exact age could be computed from biblical genealogies. The famous conclusion of Archbishop James Ussher (1581-1656) that the Creation had occurred "upon the entrance of the night preceding the twenty third day of October" in the year 4004 BC (Grayson 1983:27), was but one of the many such estimates that had been, and were to be, presented.

The works of the Danish historian Peter Friderich Suhm (1728-1798)are a typical example of this pre-modern conception of man's past. He was concerned among other things with determining the exact date of the arrival of the first inhabitants to Scandinavia. In his books Historie om de fra Norden Udvandrede Folk [History of the Nordic Emigrants] (1773) and Historie af Danmark fra de cldste Tider til Aar 803 [History of Denmark from the Oldest Times Until the Year 803] (1782), Suhm claims to have calculated the course of history following the stranding of Noah's ark on Mount Ararat. The distance from Mount Ararat to Babel, where the confusion of languages took place in the year 1757 after the Creation, is 90 German miles. The people took 101 years to travel between these two places, and this constitutes the basis for formulating a constant rate for the geographical dispersal of people. Using this formula, Suhm arrives at the conclusion that Scandinavia was first inhabited 2623 years after Creation and 865 years after the confusion at Babel. Suhm was also able to estimate the number of people in any historical period. He shows that Noahs's offspring gave birth to 16 sons. After 101 years there must have been about 3000 couples in Babel, or 16 tribes containing 375 persons each (Suhm 1773:141-159, 1782:1-2, Svestad 1993:128-130).

Suhm claimed that his history was the 
Tab. I.

Tabelle obet golfenes ubbrebelfe efter ben 20 regel.

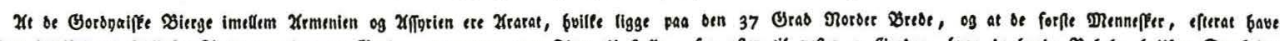

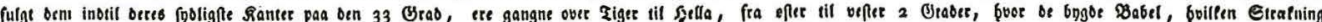

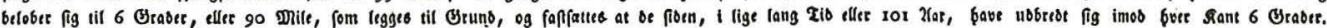

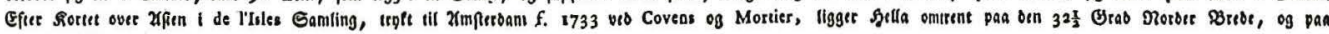
oen 62 af kangoen.

\begin{tabular}{|c|c|c|c|c|}
\hline & Rorb. & pofter. & Ginnoer. & Beffer.' . \\
\hline $\begin{array}{l}\text { I Periodus. Fra } 1757 \\
\text { til } 1858 \text {. }\end{array}$ & 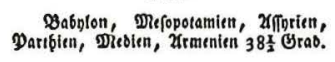 & $\begin{array}{l}\text { Babplonten, Eligmais, } \text { eus } \\
\text { fiana til } 68 \mathrm{Brab} \text {. }\end{array}$ & $\begin{array}{l}\text { Diabnlonlen, Arabis Defer- } \\
\text { in, til } 26 \frac{1}{2} \text { Urad. }\end{array}$ & 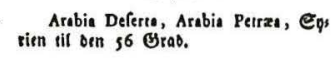 \\
\hline $\begin{array}{l}2 \text { Periodus. Fra } 1858 \\
\text { til } 1959 .\end{array}$ & 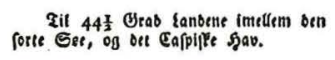 & 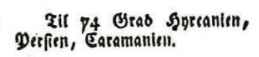 & lix. $211201 \frac{1}{2}$ Orab Arabia fe. & 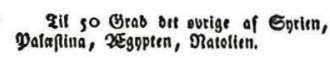 \\
\hline $\begin{array}{l}3 \text { Periodus. Sta } 1959 \\
\text { til } 2060 .\end{array}$ & 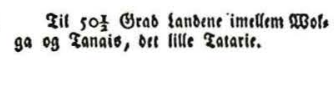 & $\begin{array}{l}\text { 2it } 80 \text { Grab Earamanien, } \\
\text { \$astriang, Eebrofia. }\end{array}$ & 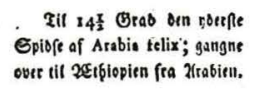 & 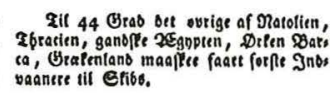 \\
\hline $\begin{array}{l}\text { 4Periodus. Bra } 2060 \\
\text { til } 216 \mathrm{r} \text {. }\end{array}$ & 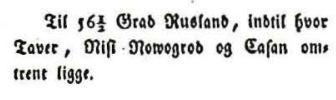 & 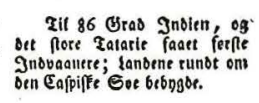 & 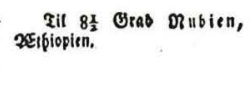 & 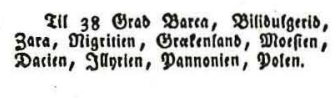 \\
\hline $\begin{array}{l}\text { SPeriodus. Fra } 2161 \\
\text { til } 2262 .\end{array}$ & 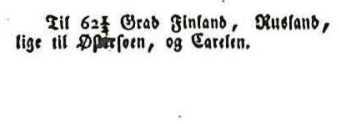 & $\begin{array}{l}\text { 2il } 92 \text { Grab Jnoien, bet } \\
\text { More Tataris. }\end{array}$ & 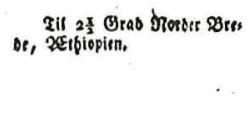 & 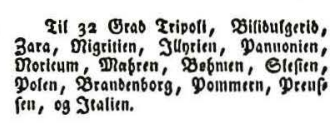 \\
\hline $\begin{array}{l}6 \text { Periodus. Sra } 2262 \\
\text { til } 2363 \text {. }\end{array}$ & Fil $68 \frac{1}{2}$ Orab Sinfanb, Saptano. & $\begin{array}{l}\text { Ril } 98 \text { Grao gndien inbs } \\
\text { til Ganges, notb paa bet Rore } \\
\text { Zatarie. }\end{array}$ & 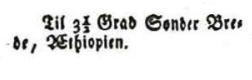 & 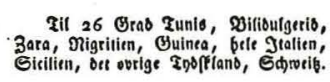 \\
\hline $\begin{array}{l}7 \text { Periodus. Fra } 2363 \\
\text { til } 2464 .\end{array}$ & 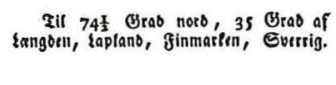 & 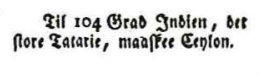 & 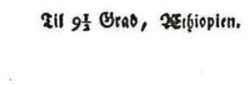 & 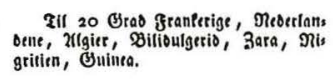 \\
\hline $\begin{array}{l}8 \text { Periodus. Fra } 2464 \\
\text { til } 2565 \text {. }\end{array}$ & $\begin{array}{l}\text { Tit } 29 \text { Brab ganofefe Evertig og } \\
\text { Dannemiar?. Poorge Oe forfer. }\end{array}$ & $\begin{array}{l}\text { Til no Brab, צnoien, ont } \\
\text { Rore Tatarie. }\end{array}$ & Fil 1 s $\frac{1}{2}$ GraO, $2 S_{1}$ ţiopien. & 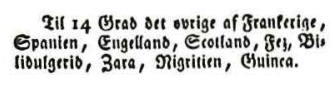 \\
\hline $\begin{array}{l}9 \text { Periodus, Fra } 2565 \\
\text { III } 2666 .\end{array}$ & Ganiofece Morge. & 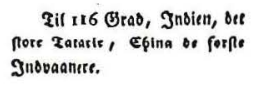 & Sill $21 \frac{x}{3}$ Grab. & 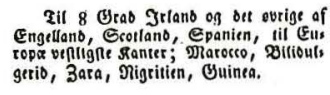 \\
\hline $\begin{array}{l}\text { Io Periodus. }\{\text { ra } 2666 \\
\text { til } 2767 \text {. }\end{array}$ & $\begin{array}{l}\text { Nu fave Inovaaneene i Morben foo } \\
\text { meret fig, on ingen fere lanbe vare bee } \\
\text { at befatte. }\end{array}$ & 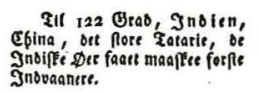 & 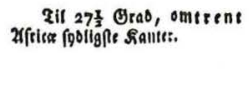 & 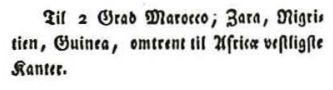 \\
\hline
\end{tabular}

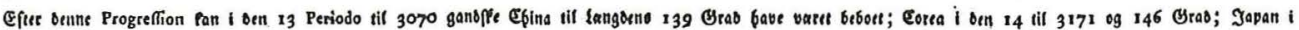

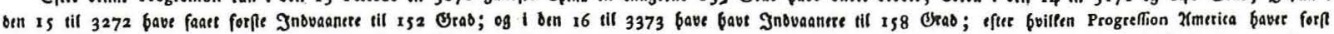

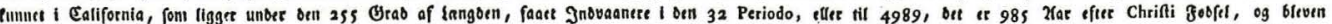

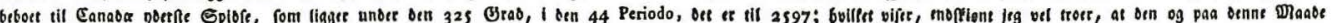

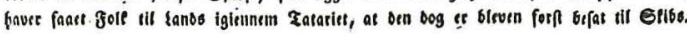

Fig. 1. Table showing the geographical dispersal of people after Babel according to Suhm's 20th rule. The left column lists the successive periods dated according to years after the creation. The remaining four columns map the limits of the distribution of people, respectively, to the north, east, south and west at any given period (from Suhm 1769).

most certain ever written (Jensen 1988:3). truths and the genealogical sequence. In a He supports this claim by establishing rules and tables covering the historical work published in 1769, Suhm established a number of rules covering increasingly 
6 more complex conditions related to the historical migrations. The first and basic rule claims that "the Bible is the primary source for fixing the origin of people", while the second ascertains that "the flood was general" (Suhm 1769:8, our translation). Suhm proposed a total of 36 rules and many of these were explained by tables incorporating language, dates, compass points and geography (Svestad 1993:129130).

Suhm's works are an excellent example of how knowledge about the past was constructed in the 17th and 18th centuries. Through mathematical calculation and the formulation of rules, Suhm manages to prove the order of history (Svestad 1993:30). His work illuminates the role mathesis played in all knowledge in this period. Things became the object of knowledge only by being measured, divided and ordered. The access to the world was immediate; language constituted the link between man and reality, understanding was equated with naming. By searching for similarities and differences, all things could be ordered within a table (Foucault 1989a).

Is it worth noting that in establishing such a general history as Suhm did, monuments and antiquities played a marginal role. Although Suhm did have some experience with archaeological material, this never constituted a basis for his historical conclusions. The reason for this seems obvious: history was a fixed scheme laid out in advance. It constituted a great, unified entity which these monuments and artefacts could hardly serve to illuminate. They were at best illustrations of the great order of history and nature.

However, in the decades around 1800 this universal and fixed chronology of a general history collapses. History no longer appears as a homogeneous and fixed order which can be presented in detailed calculated tables. One expression of this transition is that exact chronologies and tables, like those established by Suhm and others, disappear from the field of knowledge. Biblical exegeses no longer constitute the self-evident source for tracing the origin of peoples and languages. Simultaneously, a new and particular interest arises in antiquities and prehistoric monuments (Svestad 1993:154).

The conception of the past was completely changed. The certainty and self-confidence with which 17 th and 18th century scholars talked about even the most distant past were replaced by a feeling of uncertainty and loss. The past was no longer a continuous and meaningful story laid out by Genesis, but appeared as a lost time covered in darkness. It is a noticeable feature in the works of early 19th century historians and antiquarians that they often resort to metaphorical expressions such as "darkness", "fog" or "void" when addressing the prehistoric past. At the same time there is a lack of references to the flood which constituted an inevitable starting point in 17th and 18th century chronologies (Svestad 1993:154, 170-171).

One of the earliest expressions of this new attitude towards the past is the work of the Swedish scholar Nils Henric Sjöborg, Inledning Til Kännedomen af Fäderneslandets Antiquiteter [Introduction to the Knowledge of Antiquities of the Fatherland] from 1797. Here he states that:

... not without a delightful satisfaction are we disentangling the labyrinths of dusk, and when no ray 
of light will lead us, the true lover of the past will not be scared, but without resorting to fantasies and romances, he will say frankly - here is the darkness and return (Sjöborg 1797:2, our translation).

In 1806, Rasmus Nyerup, the librarian at the University of Copenhagen and first secretary of The Royal Commission for the Preservation of Antiquitues, wrote that:

... everything which is left from the oldest past, is drifting for us as in a thick fog. We know it is older than Christianity, but whether it is just a few years, hundreds, or even thousands of years older, we are only able to guess (Nyerup 1806:1, our translation).

The fixed origin which the creationist paradigm had supplied to human history was lost in the early 19th century. This erosion of a unitary, biblical chronology had left a historical void. Fixed points such as creation, the flood and Babel found no existence in this "empty space" which modern thought introduced into history. However this did not put an end to history, quite the reverse: through the discovery of this abyss history could now begin. It was exactly this loss, this open space, which created the possibilities for an archaeological study of prehistory.

How can this be explained? If early 19th century men and women felt such a historical loss, how should we then explain this simultaneous curiosity for history and for antiquities and prehistoric monuments?

In his "archaeology of the human sciences", the French philosopher Michel Foucault has decribed this break as a situation where man found himself in a dehistoricized condition. He states that:
... the imaginative values then assumed by the past, ... the conciousness of history of that period, the lively curiosity shown for documents and for traces left behind by time - all this is a surface expression of the simple fact that man found himself emptied of history (Foucault 1989a:369).

But, as Foucault continues, this curiosity was also a sign

that he was already beginning to recover in the depths of his own being, and among all the things that were still capable of reflecting his image, ... a historicity linked essentially to man himself (1989a:369).

According to his argument it is only by acknowledging that we have lost history that we are able to recover it. It is the lack of a fixed chronology and detailed knowledge of the past which creates a historical consciousness. History was no longer a secure and fixed foundation but an uncomfortable abyss which had to be filled. The new interest in monuments and antiquities in the early 19th century is related directly to this recovery. Material remains became both witnesses to a lost origin and the promises of its return. The traces which prehistoric humans have left, the objects they have made, appear as a manifestation of a lost origin which only these objects themselves make it possible to recover (Svestad 1993:154).

Material remains have their own historicity which the historian and archaeologist have to reveal. From now on their work expresses a connection between antiquities/monuments and history which was not articulated earlier. It is interesting to note that in 1806, Rasmus Nyerup refers to the earth as an archive, and to the prehistoric remains as documents stored in that archive (1806:3). This reveals a faith, if yet un- 
8 rewarded, in the way these material remains might be able to inform us about the past.

Some decades later, in 1836 when the fog had started to clear, Christian Thomsen and others expressed this new faith in prehistoric remains in an illuminating way with an article in Ledetraad til nordisk Oldkyndighed og Historie [English version "Guidebook to Nordic Antiquity" published in 1848]:

... they enable us to rise up to our Nordic "urvolk", they enable us to re-live our forefathers' lives and to wander among them. A burial mound, a single stone circle, a stone artefact or a metal ornament (Thomsen et al. 1836:28, our translation).

Contrary to earlier conceptions, antiquities and monuments are not mere illustrations of the great order of history but reflect the inner life of man. They hide the secret of life itself and through these material remains we are able to trace an origin and to re-enact the past (Johnsen and Olsen 1992).

Thus, what characterizes the earliest decades of the 19th century is the appearance of a new historical consciousness. The realization of an almost totally unknown past, as expressed in currently utilized metaphors such as "darkness" and "thick fog", is a manifestation of these changed conditions and forms the "object" for an epistemology about prehistory. In a manner similar to that in which philology was tracing the authentic condition in spoken words to find the system and history of languages, archaeology turned to the material remains themselves to construct its own independent system. The three-age system represents a tempo- rary culmination of this epistemology (Svestad 1993:170).

Although archaeology did not yet constitute a formalized scientific practice, a very important step had been taken. As stated in the preface to the periodical Annaler for Nordisk Oldkyndighed (Annals of Nordic Antiquarian Knowledge) published in 1837:

... we may already now have a legitimate hope that our archaeology in the future could deserve the name of a science, which to a considerable extent could compensate for the loss of our oldest history (Det Kongelige Nordiske Oldskrifts-Selskab 1837, our translation).

\section{MUSEUMS AND ARCHAEOLOGY IN 19TH CENTURY}

The study of material remains from the past did not constitute a separate field of study in Scandinavia before the 19th century. Before this century it is impossible to speak of a discipline of archaeology and to an even lesser extent of archaeological museums. Rewriting Foucault's famous statement about marxism (1989a:262), we may say that archaeology exists in 19th century thought like a fish in water: that is, it is unable to breathe anywhere else.

In the 17th and 18th centuries there were no enabling conditions for an epistemology of prehistory or of prehistoric objects. There were of course deeper layers of knowledge which affected the way antiquities were perceived, but no exclusive epistemology like that which emerged in the 19th century. In the 17th and 18th centuries, being was spread out over an immense table, a universal taxonomia. Life was the province of an ontology which 
dealt in the same way with all material beings (Foucault 1989a:273). In this discursive formation there was no space for a separate archaeological or antiquarian field of knowledge.

What may be termed antiquarianism in Scandinavia in the previous centuries was expressed in different fields, and carried out by different professionals such as priests (Pontoppidan), medical doctors (Rudbeck) or natural historians (Stobæus). Even if there were attempts at classifying and systematising antiquities, it is impossible to find a similar, overarching systematics as in natural history as represented by Linneus. It is true that antiquarianism was linked to natural history through many of the natural cabinets and collections. People like Stobæus, Pontoppidan, Bircherod and others had personal collections of natural artefacts which also contained coins and prehistoric objects. In general terms, however, antiquarianism represented a far less formalised system of knowledge than did natural history in the 17 th and 18 th century. It is primarily by being separated from natural objects and through some initial attempts at classifying antiquities that antiquarianism in Scandinavia reflects the order of this period (Svestad 1993:132-133).

As noted above, this situation was dramatically altered at the beginning of the 19 th century. From occupying a marginal position in the field of knowledge in the 17 th and 18th century, prehistory and antiquities now entered the very heart of a discourse designed to suit them.

A symptomatic manifestation of this new development is the establishment of The Royal Commission for the Preservation of Antiquities in 1807. It began to amass a collection of artefacts from all over Denmark, and this collection soon became one of the largest and most representative in Europe. In Norway a similar commission was established in 1811 (Klindt Jensen 1975).

The secretary of the Danish commission, Rasmus Nyerup, had published a book one year earlier with the quite expressive title Oversyn over Fadernelandets Mindesmarker fra Oldtiden, saaledes som samme kan tonkes opstillede i et tilkommende National-Museum [Survey of the National Monuments of Antiquity, such as they may be displayed in a future National Museum] (1806). In this work, Nyerup presents a detailed and ambitious plan for how a National Museum for Denmark and Norway should be organized. This museum should be divided into three main halls containing respectively, prehistoric monuments, runic inscriptions and Christian remains. The prehistoric hall, or the hall from the savage past, should be further subdivided into two rooms, one containing purely prehistoric monuments and objects, while the other was intended to contain monuments with certain historical traditions. In his introduction to the description of the first of these rooms, Nyerup states that:

Prehistory is laid out before all time, before any determination of time. Thus, this room contains monuments and remains whose age goes so far back, that no dating can take place ... it can only be said to be indefinitely old. Everything that belongs to this period drifts before us as in a thick fog (Nyerup 1806:1, our translation).

Describing the difference between this room and the next, Nyerup continues in a 
10 similar manner:

In the next room the visitor somehow enters a quite different world. Unlike the first room, where he was surrounded by an almost totally impenetrable chronological darkness, the dawn of the historical day starts here, and occasionally there is a dim light (Nyerup 1806:89, our translation).

Nyerup's detailed discription of the contents of the various halls in this future national museum provides a fascinating picture of how prehistory was perceived at the beginning of the 19th century. However, it is even more interesting to ask why Nyerup wanted to produce such collections of prehistoric remains when so little was known about their dating and cultural origin. Why should anyone want to wander among objects whose age and meaning were said to be "drifting before us as in a thick fog"?

There are certain statements in Nyerup's work, and in the work of others, which point to some interesting reasons for this seemingly paradoxical plan of displaying that which is almost totally unknown. Nyerup himself provides a hint in the following statement about the displayed artefacts:

Here these strange remains from the past are displayed in long rows, which makes contemplation of the things themselves a clearer idea (Nyerup 1806:2, our emphasis and translation).

In his "comments" related to the establishment of The Royal Commission for the Preservation of Antiquities, published in 1808, the historian Erik Werlauff expresses this view even more clearly. He writes:

... only when all mobile antiquities are collected and displayed in a museum, has the time come for the archaeologist to survey and arrange all these materials, and if possible, to construct from them a system. Only then is he able to decide what we are still with some certainty able to know (Werlauff 1808:61, our emphasis and translation).

Thus, only by studying the material remains themselves are we able to bring the distant past closer in order to know it. The word "still" in Werlauff's statement points to the new uncertainty which the collapse of the former episteme has brought about. It is interesting to note that when the system Werlauff was predicting had come into use to some extent, in terms of the three-age system, there is similar credit given to the museum. Thus in 1833, Magnussen, Thomsen and Rafn, all members of the Antiquities Commission, wrote that:

Among our antiquities the stone artefacts are believed to be those which may belong to the most distant period of time ... However it is only in the most recent years that, due to the establishment of larger public museums, we have gathered such a collection from different regions of the Nordic countries that we have been able to think more seriously about arranging these antiquities into classes with subdivisions, and to suggest that fixed concepts be used to designate the different forms (Magnusen et al. 1833:421, our emphasis and translation).

Related views are expressed still later by Christian Herbst who in 1861 wrote that "by comparing and repeatedly investigating the details in the museum, the eye is sharpened to make new observations and discoveries" (Herbst 1861:306, our translation).

The content of these statements makes 
this a timely place to proceed to the next part of this paper which deals with museums and the representation of the past.

\section{MUSEUMS AND THE REPRESENTATION OF THE PAST}

As the Dutch anthropologist Johannes Fabian has noted, the traditional problem with representations has been their "accuracy", the degree of fit between reality and its reproduction in knowledge and language (Fabian 1990:754). This of course, is also a classic problem in archaeology. For example, in what way are typology or the three-age systems correct representations of prehistoric realities? Similar questions have been raised in museology by Eileen Hooper-Greenhill who asks, "If new taxonomies means new ways of ordering and documenting collections, then do the existing ways in which collections are organised mean that taxonomies are in fact socially constructed rather than 'true' or 'rational'?" (Hooper-Greenhill 1992:5).

In the introduction to this paper, we made some statements which questioned the idea that our concept of prehistory precedes an archaeological discourse, and we shall now elaborate a little on this point. In very general terms, knowledge is traditionally defined as the correct depiction of reality which mirrors the essence of its subject matter (Rorty 1979). Our position questions this mirror-image view of knowledge and suspends the assumed correspondence between knowledge and reality. Knowledge, and what is allowed to count as such, are regarded as constituted within semantic fields, discourses and tradition. Rather than imitating reality, knowledge and language help to constitute it.

In terms of archaeology, this implies that archaeological statements, like books and museum exhibitions, create not only knowledge of the past but, at least to a certain degree, also the very reality they intend to describe. Taking this view seriously, we should be willing to accept that it is the various textual and museological techniques of representation in the present that make the past visible and clear, and that these representation rely upon institutions, traditions, conventions, and agreed-upon codes of understanding the past (Olsen 1991).

Edward Said's work Orientalism (1978) in our opinion exposes this problem of representation very well. Here he shows how representations of the Orient in Western discourse form self-sufficient systems which have constructed and objectified the Orient for our perception. Said uses the concept of "strategic formation" to analyse the representational archive from which the Orient is created. This concept designates the "relationship between texts and the way in which groups of text, types of text, even textual genres, acquire mass, density, and referential power among themselves and thereafter in the culture at large" (Said 1978:22). Following this line of argument one may regard the 19th century archaeological museum as part of such a strategic formation where words and things such as books, catalogues and objects, and typological and chronological schemes, communicated and referred to each other in a vast representaional web. This web created prehistory as an object of knowledge and covered up that empty space which modern discourse had created. 
12 The statements from Werlauff, Nyerup and Thomsen referred to above, all underline the creative role assigned to the museum collections and arrangements. Even though it is likely that these pioneers believed that the system they were establishing provided correct representations, their statements do point to the creativeness of museum arrangements. In 1926, the Norwegian archaeologist Anton Wilhelm Brøgger expressed this view even more clearly:

This main division of our country's prehistory which is known through the scheme Stone Age, Bronze Age and Iron Age, has never aimed at a real representation of the construction of our prehistoric culture ... It is a necessary chronological scheme to be used to order materials of such a quantity that it would have been chaos without the help of this scheme (1926:1, our translation).

Brøgger emphasises that typology provides a means of handling and organizing immense amounts of material. However, despite this apparent consciousness which Brøgger expresses with respect to typology as an ordering scheme, it had nevertheless become an indispensable part of archaeological reasoning. During the last decades of the 19th century, typology became the main ordering principle for all statements regarding prehistoric material. In the museums every statement about the past was filtered through this epistemological grid. By being uttered in an enormous number of textual and museological statements, typology was established as a fact and became an archaeological a priori. It would be naive not to realise that this fact in turn reflected back upon the way the past was perceived. Thus, exhibited arte- facts become statements which substantiated the very system they themselves were the result of.

Analysing the role of the museum in the creation of an archaeological discipline, it is not sufficient to ask what the museum represents. We have to ask how it represents. In what way did it enable some ways of knowing while preventing others? What rules and techniques were utilised to discipline the past and to create prehistory as an object of knowledge?

Analysing how institutional power operates through processes of objectification, Michel Foucault (1979) has introduced the concept of "disciplinary technologies". These technologies includes institutions such as prisons, hospitals, factories and schools. Disciplinary technologies work in several related ways; they survey, classify and control time, space, bodies and things. Discipline proceeds from an organization of individuals in space, and it requires not only a specific enclosure of space but also an internal partitioning of this space (Foucault 1979:141-143). Once established, this grid permits the certain distribution of the individuals who are to be disciplined and supervised. It organises an analytical space "aimed at knowing, mastering and using" (Foucault 1979:143).

One of the most notable features of 19th century disciplinary museums were the new organization of space, both in terms of the external enclosure of the subject matter and in terms of the internal divisions (cf. Hooper-Greenhill 1992:168 ff). In historiographies of archaeology, however, this basic premise is rarely, if ever, given attention. Although prehistoric artefacts had been collected and put on display far earlier, as in the Renaissance 
Fig. 2. "A vast documentary apparatus become an essential part of this normalization". From the halls of the State Historical Museum, Stockholm, in the early years of this century (photo: ATA, 1484:11).

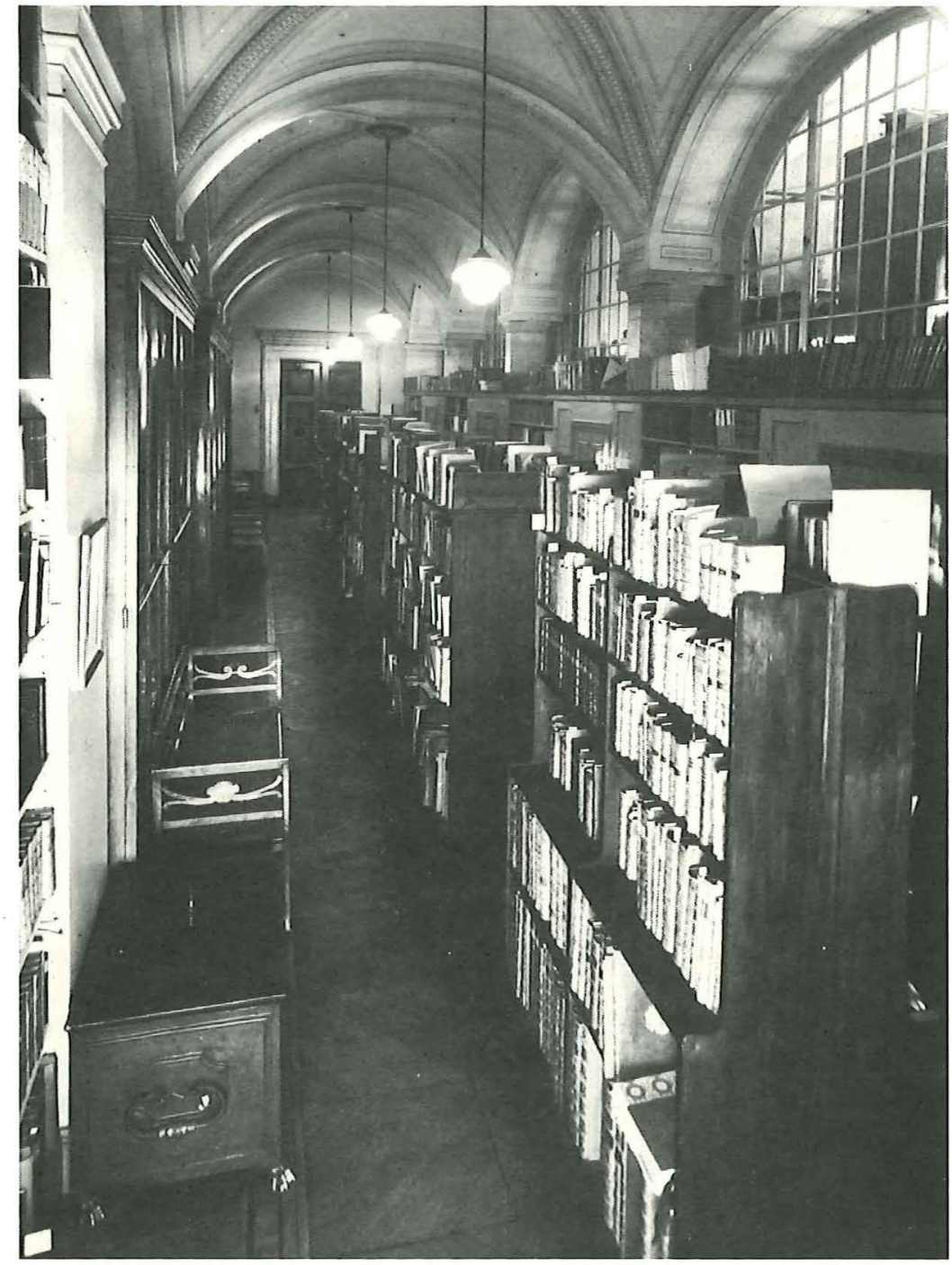

cabinets, and to some degree had even been separated from other objects, as for example in the Royal Kunstkammer in Copenhagen (Bencard 1993), the new museological institutions made this spatial division far more exclusive. Prehistoric objects were no longer to be found among conches and fossils. These "dividing prac- tices", happened first and most often as internal departmental divisons of larger museums. Collections of prehistoric remains were exhibited and archived in separate rooms or halls. Later on in the century, even separate archaeological museum buildings came into use. This process, of course, was not restricted to 
14 archaeology. It took place simultaneously in other disciplines as well, such as ethnography and the natural sciences.

It is inevitable that this basic separation affected the way the past was perceived and clearly contributed to the objectification of the past as a single and unified subject for study. In this process of objectification and categorization, the past is given both a social and a scientific identity. Instead of drifting in the dark, the past could now be looked at, touched, spoken about. It was real and visible; it was there.

This external separation, however, represents only an initial step in this process. Even more important for the epistemologisation of prehistory was the internal divison of collections and exhibitions according to types and chronological phases. This internal division organized and arranged space to facilitate the correct observation of the past. It located groups of artefacts in space, in a hierarchical and efficiently visible organization. And most important, it made possible a system of "normalization" (Foucault 1979) with finely gradated and measurable intervals in which objects can be distributed according to a typological norm - a norm which both organizes and is the result of this controlled distribution in space (Rabinow 1984:20).

A vast documentary apparatus became an essential part of this normalization. Museum exhibitions began to be supported by a number of detailed illustrated catalogues and material publications. Throughout the 19th century an increasingly finer grid of typologies based on more precise and more statistically accurate measurements enabled archaeologists to fix knowledge of the past in a web of objective codification. In conjunction with these new divisions of the perceptual field, new groups of statements were to be made (Hooper-Greenhill 1992:179). Classes of artefacts were singled out, they became named and together with a growing number of archaeological concepts such as type, find context, stratigraphy, culture, etc., resulted in an archaeological discourse reinforcing itself to an ever increasing degree (Brattli 1993:147). By the end of the century archaeology had reached the level of a formalised, partly self-sufficient, discourse of prehistory.

Museums, as a kind of disciplinary technology, did not cause the development of an archaeological discipline. However, they were the prerequisites for its success.

\section{THE AUTHORIZATION OF VOICES}

By the end of the 19th century a certain kind of archeological genre or style had appeared. This archaeological style, or what we may term a certain constant manner of utterances, can be characterized in terms of a dominant trope which establishes the originating relationship between "words" and "objects" and determines what can be said about things in a "proper" archaeological discourse. This further determines both what can be seen in archaeological material and what can be known about it. Archaeology, as a discipline, consisted of a corpus of knowledge that presupposed the same way of looking at things (Foucault 1989b:33).

This genre is expressed in monumental works which appeared in the last decade of this century such as Sveriges Forntid [The Antiquity of Sweden] (1872) by Oscar Montelius, Norske Oldsaker [Nor- 
Fig. 3. "Within archaeological institutions judgements and diagnoses began to be made concerning proper and and inproper ways of conceiving the past. New subject positions emerged, and it became increasingly more important to separate amateurs and dilettants from professionals". Oscar Almgren studying a pot sherd in the Stone Age collection, State Historical Museum, Stockholm, in 1903 (photo: ATA, 2027:24)

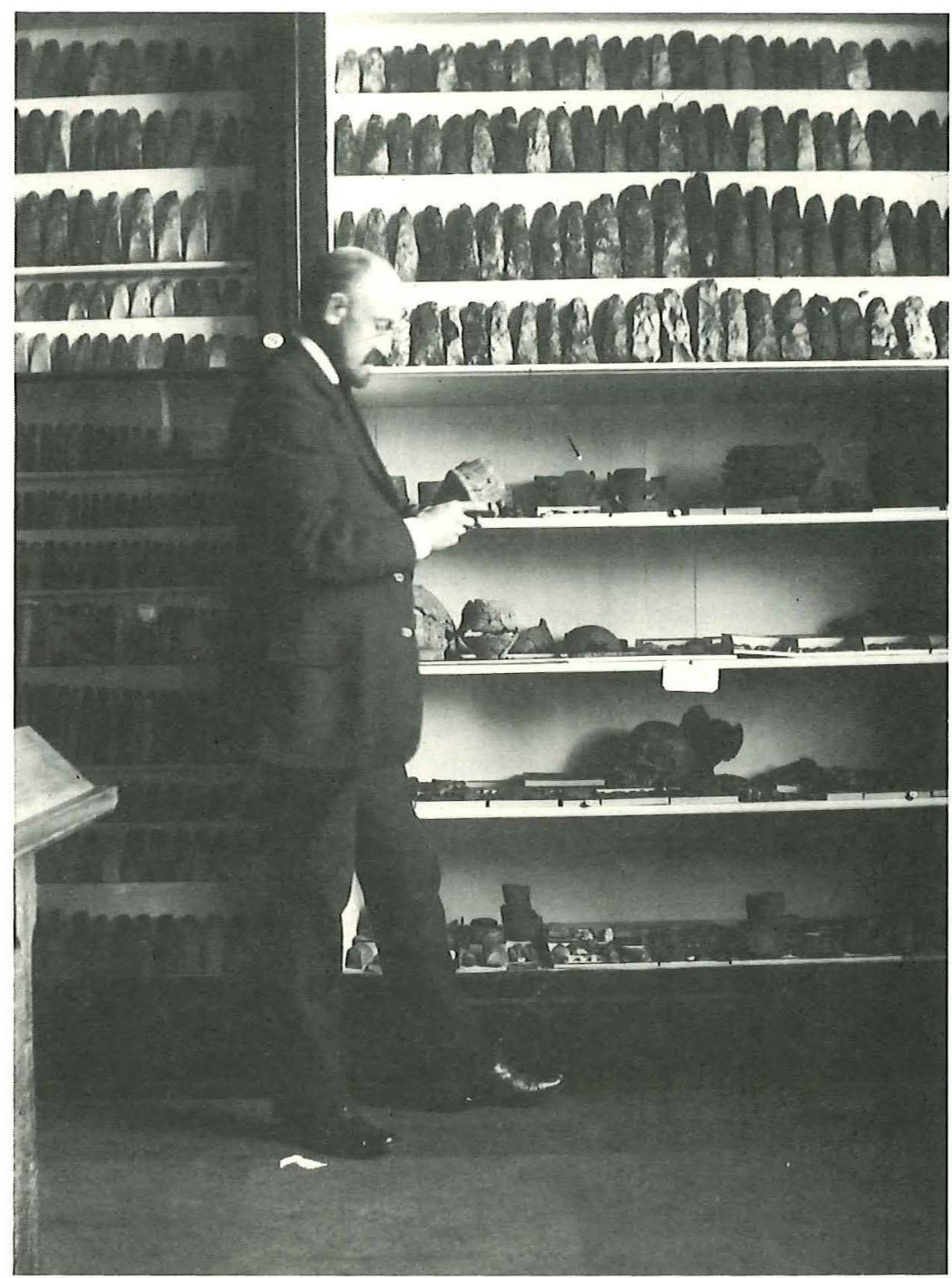

surements. Another striking feature of this genre is the way methodological issues are highlighted, exemplified in the famous debates between Oscar Montelius and Sofus Müller. This reveals a self-confident and formalized discourse based on qualitative description, reasoning by analogy, induction and deduction, statistical calcu- wegian Antiquities] (1885) by Oluf Rygh and Ordning av Danmarks Oldsager [Arrangment of the Antiquities of Denmark] (1888-1895) by Sophus Müller. In these, as well as numerous other works, the presentation of prehistoric material culture is formalised by means of figures, schemes and objective descriptions based on mea- 
BJørnar OLsEn \& Asgeir SVESTAD

16 lation, and many other forms of statement (Brattli 1993:146-149, Svestad 1993:207209).

Another sign of this formalization is a growing number of critical statements regarding earlier approaches. Thus, in 1898 Julius Petersen makes the following characterization of antiquarian practice in the 17 th and 18 th century:

Such was the naive-fantastical time ... historical critique ... was almost non-existent, scientific possiblities were put forward with much force as if they were proved facts, and one feather easily became five fowls ... especially in the areas of prehistory, archaeology and antiquity, it was the case that you could put the pieces wherever you liked (Petersen 1898:22-23, our translation).

Petersen's statement leaves no doubt that this was definetly not the case anymore.

In this sense it is impossible to discuss the role of the museum without also considering the relationship between knowledge and power. Within archaeological institutions and organizations judgements and diagnoses began to be made concerning proper and inproper ways of conceiving the past. New subject positions emerged, and it became increasingly more important to separate amateurs and dilettantes from professionals (Brattli 1993: 147-148). As Hans Hildebrand wrote in 1873:

In this way the scientific study of the past has advanced beyond its earlier state. The viewpoints have become higher, the field wider, and one has learnt in one's work to penetrate more deeply. Archaeology in this state demands the undivided attention of a whole life, it is much more than a pastime for the leisure hours. It is no longer so that the dilettante is just a little more cursory than the scientist and the latter a bit more painstaking than the former. Between them there is a great difference, they work in different ways, on different levels and towards different goals (Hildebrand 1873:13, our translation).

This relates of course to the creation of a social and scientific identity for the archaeologist. Archaeological statements can no longer just come from anyone; their value, efficacy, importance, in short their status as serious speech acts about the past, depend upon who is speaking. Whom among the totality of speaking individuals is accorded the right to use this sort of language (Foucault 1989b:50)? In the 19 th century, discourses of knowledge were to an ever increasing degree forced into institutional locations. The institutional sites grant the discourses their authority and give them a supportive ground. An archaeological discourse became authorized by being uttered from the museum. It is the proper institutional location for an archaeological discourse, the site from which this discourse derives its legitimate source and point of application. Thus, in the same manner that a serious medical speech act is uttered from the hospital, a serious speech act about the past has to come from the museum.

\section{CONCLUSION}

In 1962 the Danish archaeologist Johannes Brøndsted wrote that if one looks back to the beginning of the 19th century, there is one condition to be noticed:

What then strikes us with astonishment is that enormous difference in their knowledge about the 
past compared to ours. Let us look only at the knowledge of dating and time determination. Then: nothing. Now: It is all served, the whole development of the culture is illuminated and arranged in columns, frames and schemes (in: Brøndsted 1969:14-15, our translation).

Brøndsted's statement illustrates very well

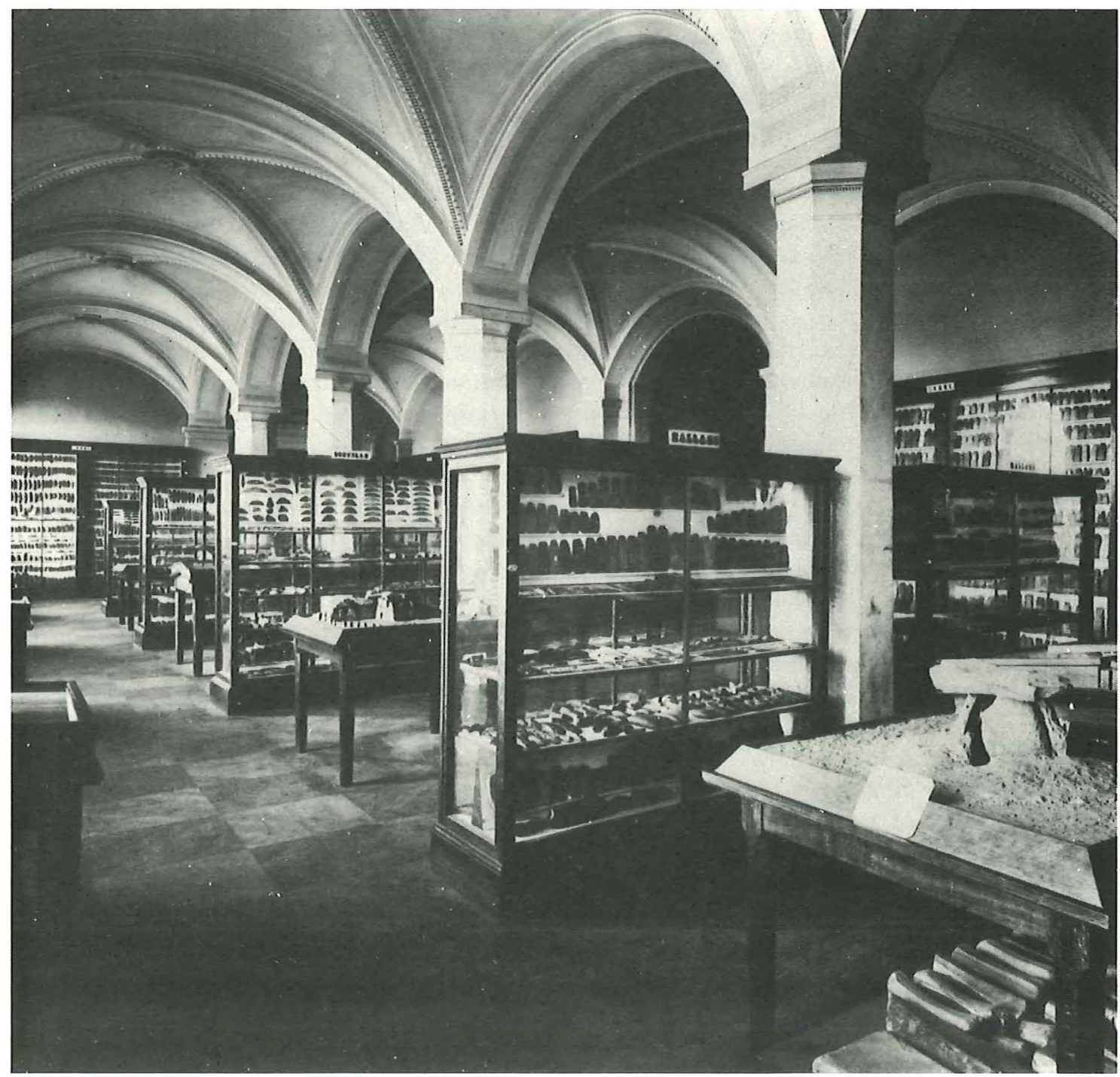

Fig. 4. The recovered past as exemplified by the Stone Age exhibition at the State Historical Museum, Stockholm, in 1903. (photo: ATA, B 108:113). 
18 the "self confidence" of modern archaeology. And he is right to stress the enormous contrast with the early 19th century's knowledge of the past. This period was "suffering" from the void which the advent of modernity had left in history. The past was no longer a fixed scheme laid out by Genesis but appeared as an empty space covered in darkness. We have argued that it was by acknowledging this loss that a historical consciousness was created. This directed a totally new interest towards past material culture. The material traces appear as a manifestation of the lost past and become the promises of its return.

At the end of the 19th century the situation changed dramatically. The past was no longer floating in complete darkness; the void which modernity had created was filled. Pictures of archaeological collections and exhibitions from the turn of the century illustrate in a very literal sense this recovery. They show us cabinets and showcases totally overcrowded with flint axes, daggers, chisels and iron swords. There was definitely no longer a void (Svestad 1993:210-211,213).

These crammed showcases with little empty space are more than a metaphorical expression of a newly recovered past. They were part of a vast formation which constructed and objectified the past for archaeological perception. The various textual and museological techniques of representation made the past visible and real. It was given a scientific and public identity which was previously lacking. Moreover, it shows archaeology as a "self confident" discipline which refers to itself by focusing on its own material. It is by establishing its own practice that archaeo- logy appears as a science, and it was by turning back upon its own material that this practice became formalized (Svestad 1993:213).

We have argued that the archaeology museum was far more than a reflection of an increase in archaeological knowledge or a result of a successful politics of collecting. The museum played a creative role both as a representational device and as a type of disciplinary technology. However, this should not take us to the other extreme of making the museum the prime force in this development. Discussing these issues, we have deliberately decided not to talk only about museums. Museum collections and exhibitions were probably among the most important fields for establishing and formalizing an archaeological discourse. However, to understand the specific importance attached to this institution we have to analyse its relationship to textual production, educational systems, new subject positions, systems of publication, fieldwork methodology, etc. In other words, the role of collections, exhibitions, in short of museums, can never be understood in isolation from other statements and practices. They have attained importance due to their "vibrations" with associated fields, with other statements and practices which in turn were themselves supported by the new technologies of the museum. 


\section{LITERATURE CITED}

Bencard, M. 1993. Museerne og Verdensordenen, Kunstkammerets opståen og grundidé. Nordisk Museologi - 1, pp.3-16.

Brattli, T. 1993. Evolusjonismen og det moderne. Ein analyse av tilkomsten av arkeologien som vitskapleg disiplin. Unpublished magister thesis, University of Tromsø.

Brøgger, A.W. 1926. Veid og Ver. Unpublished manuscript. Oslo.

Brøndsted, J. 1969. Danmarks Historie. Volume I. De ældste Tider indtil år 600, pp.11-44.

Daniel, G. 1971. The Idea of Prehistory. Penguin Books Ltd., Harmondsworth.

Daniel, G. 1978. 150 Years of Archaeology. Duckworth, London.

Det Kgl. Nordiske Oldskrift-Selskab 1837. Preface in Annaler for nordisk Oldkyndighed 1836-37.

Fabian, J. 1990. Presence and Representation: The Other and Anthropological Writing. Critical Inquiry, vol. 16 (4), pp. 753-772.

Foucault, M. 1979. Discipline and Punish: The Birth of the Prison. Vintage Books, New York.

Foucault, M. 1989a. The Order of Things: An Archaeology of the Human Sciences.

Tavistock/Routledge, London.

Foucault, M. 1989b. The Archaeology of Knowledge. Routledge, London and New York.

Grayson, D.K. 1983. The Establishment of Human Antiquity. Academic Press, New York.

Herbst, C.F. 1865. Varplev Fundet. Annaler for nordisk Oldkyndighed og Historie 1861, pp.30522.

Hildebrand, H. 1873. Den vetenskapliga fornforskingen, hennes uppgift, behof och rätt. Stockholm.

Hooper-Greenhill, E.1992. Museums and the Shaping of Knowledge. Routledge, London.

Jensen, J. 1988. Christian Jürgensen Thomsen: An Appreciation in the Bicentennial of his Birth. Acta Archaeologica, 1987, vol. 58, pp.1-15.

Klindt-Jensen, O. 1975. A History of Scandinavian
Archaeology. Thames and Hudson, London.

Kristiansen, K. 1981. A social history of Danish archaeology (1805-1975). In G. Daniel (ed.), Towards a History of Archaeology, pp. 72-100.

Magnusen, F., Thomsen, C.J. \& Rafn, C.C. 1833. Kortfattet Udsigt over nordiske Steen-Oldsager fra den hedenske Tid, med kobberstukne Afbildninger. Nordisk Tidsskrift for Oldkyndighed, vol. 1.2., pp.421-39.

Montelius, O. 1872. Sveriges Forntid. Försök till framställning af den svenska fornforskningens resultat. Atlas. Svenska fornsaker ordnade och förklarade, I. P. A. Nordstedt \& Söner, Stockholm.

Müller, S. 1888-95. Ordning af Danmarks Oldsager. København.

Nyerup, R. 1806. Oversyn over Fædernelandets Mindesmærker fra Oldtiden, saaledes som samme kan tænkes opstillede i et tilkommende NationalMuseum. Et Forsøg. Historisk-statistisk Skildring af Tilstanden $i$ Danmark og Norge $i$ aldre og nyere Tider. Vol. 4.

Olsen, B. 1991. Kjelmøyfunnenes (virknings) historie og arkeologi. Viking, vol. LLIV, pp.65-87.

Patterson, T.C. 1986. The Last Sixty Years: Towards a Social History of Americanist Archaeology in the United States. American Anthropologist, 88 (1):7-26.

Petersen, J. 1898. Bartholinerne og kredsen om dem. København.

Rabinow, P. 1984. Introduction. In P. Rabinow (ed.), The Foucault Reader. Penguin Books, Harmondsworth, pp. 3-29.

Rorty, R. 1979. Philosophy and the Mirror of Nature. Princeton University Press, Princeton.

Rygh, O. 1885. Norske Oldsager. Kristiania.

Said, E.W. 1978. Orientalism. Routledge \& Kegan, London.

Sjöborg, N.H. 1797. Inledning Til Kännedomen af Fäderneslandets Antiquiteter. Lund.

Suhm, P.F. 1769. Forsøg til et Udkast af en Historie over Folkens Oprindelse i Almindelighed som en Indledning til de Nordiske Folkes $i$ Serdeleshed. 
BJørnar OlsEn \& ASgeir SVESTAD

20 København.

Suhm, P.F. 1773. Historie om de fra Norden

Udvandrede Folk. Vol. II. København.

Suhm, P.F. 1782. Historie af Danmark fra de aldste Tider til Aar 803. I. Tome. København.

Svestad, A. 1993. Oldsakenes orden. Ein analyse av forskarar og "forbistorisk" kunnskap i tida 1600-

1900. Unpublished magister thesis, University of Tromsø.

Thomsen, C.J. et al. (unspecified members of The Royal Commission for the Preservation of Antiquities) 1836. Kortfattet Udsigt over Mindesmærker og Oldsager fra Nordens Fortid. Ledetraad til nordisk Oldkyndighed og Historie, pp.37-91. Published by Det Kgl. Nordiske Oldskrift-Selskab.

Trigger, B. 1989. A History of Archaeological Thought. Cambridge University Press, Cambridge.

Werlauff, E.C. 1808. Bemarkninger i Anledning af den, til de nordiske Oldsagers Samling og Opbevaring nedsatte Commission. København.

Björnar Olsen är frän 1994 professor $i$ arkeologi vid Tromsö universitet. Asgeir Svestad är mag.art.i arkeologi, frän hösten 1994 fylkesarkeolog i Finmark.

Adr: Institutt for Samfunnsvitenskap, Universitetet $i$

Tromsø, N-9037 Tromsø, fax +47-77644905 